\title{
The Pico de Navas slump (Burgos, Spain): a large rocky landslide caused by underlying clayey sand
}

\author{
E. Sanz-Pérez ${ }^{1}$, I. Menéndez-Pidal ${ }^{1}$, A. Lomoschitz², R. Galindo-Aires ${ }^{1, *}$ \\ ${ }^{1}$ Escuela Técnica Superior de Ingenieros de Caminos, Canales y Puertos. Universidad Politécnica de Madrid, Spain. \\ ${ }^{2}$ Escuela de Ingenierías Industriales y Civiles. Universidad de Las Palmas de Gran Canaria, Spain. \\ e-mail addresses: rubenangel.galindo@upm.es (R.G-A, corresponding author),esanz@caminos.upm.es (E.S-P),impidal@caminos.upm.es(I.M-P), \\ alejandro.lomoschitz@ulpgc.es (A.L).
}

Received: 31 July 2015 / Accepted: 1 March 2016 / Available online: 30 April 2016

\begin{abstract}
The Pico de Navas landslide was a large-magnitude rotational movement, affecting 50x $10^{6} \mathrm{~m}^{3}$ of hard to soft rocks. The objectives of this study were: (1) to characterize the landslide in terms of geology, geomorphological features and geotechnical parameters; and (2) to obtain an adequate geomechanical model to comprehensively explain its rupture, considering topographic, hydro-geological and geomechanical conditions.

The rupture surface crossed, from top to bottom: (a) more than $200 \mathrm{~m}$ of limestone and clay units of the Upper Cretaceous, affected by faults; and (b) the Albian unit of Utrillas facies composed of silty sand with clay (Kaolinite) of the Lower Cretaceous.

This sand played an important role in the basal failure of the slide due to the influence of fine particles (silt and clay), which comprised on average more than $70 \%$ of the sand, and the high content presence of kaolinite $(>40 \%)$ in some beds. Its microstructure consists of accumulations of kaolinite crystals stuck to terrigenous grains, making clayey peds. We hypothesize that the presence of these aggregates was the internal cause of fluidification of this layer once wet. Besides the faulted structure of the massif, was an important factor for the occurred landslide. Other conditioning factors of the movement were: the large load of the upper limestone layers; high water table levels; high water pore pressure; and the loss of strength due to wet conditions.

The numerical simulation of the stability conditions concurs with our hypothesis.

The landslide occurred in the Recent or Middle Holocene, certainly before at least $500 \mathrm{BC}$ and possibly during a wet climate period. Today, it appears to be inactive.

Due to mineralogical features of involved material, facies Utrillas, in the landslide, the study helps to understand the frequent slope instabilities all along the Iberian Range where this facies is present.
\end{abstract}

Keywords: deslizamiento rotacional, Cordillera Ibérica, facies Utrillas, Cretácico, simulación numérica

\section{Resumen}

El deslizamiento de Pico de Navas fue un movimiento rotacional de gran magnitud, que involucró 50x $10^{6} \mathrm{~m}^{3}$ de rocas. Los objetivos de este trabajo han sido: (1) caracterizar el deslizamiento a partir de la Geología, los elementos geomorfológicos y los parámetros geotécnicos; y (2) obtener un modelo geomecánico que permita explicar adecuadamente la rotura, teniendo en cuenta la topografía, previa y posterior al movimiento, y las condiciones hidrogeológicas y geomecánicas.

La superficie de rotura atravesó, de arriba abajo: a) $200 \mathrm{~m}$ de calizas y arcillas del Cretácico superior, afectadas a su vez por fallas, y b) la unidad del Albense de facies Utrillas, compuesta de arenas limosas con arcilla (caolinita) del Cretácico Inferior. Las facies Utrillas tuvieron un papel importante en la rotura basal del deslizamiento debido a la influencia de las partículas finas (limos y arcillas) que alcanzan el 70\% de media y el alto contenido en caolinita, $>40 \%$ en algunos niveles. Tienen una microestructura particular: al microscopio electrónico se ven paquetes de cristales de caolinita pegados sobre los granos de terrígenos, formando agregados porosos. Se propone que la formación de estos agregados sea la causa intrínseca de la fluidificación de los niveles de arenas caoliníticas del Albiense.

Entre los factores condicionantes del movimiento destacan: la estructura fallada del macizo, la gran carga vertical trasmitida por las capas de calizas superiores; los elevados niveles freáticos, la alta presión de poros y, en consecuencia, la disminución de los parámetros resistentes. 
El modelo geomecánico ha permitido simular las condiciones de estabilidad y rotura del deslizamiento, cuyos parámetros y condiciones coinciden con las anteriormente indicadas.

El deslizamiento se produjo en el Holoceno Reciente o Medio, con certeza antes del S.V AC y posiblemente durante un periodo climático húmedo. Ahora el deslizamiento es inactivo. Este trabajo ayuda a entender las frecuentes inestabilidades de laderas y taludes asociados a las facies Utrillas, a lo largo de la Cordillera Ibérica.

Palabras clave: deslizamiento rotacional, Cordillera Ibérica, facies Utrillas, Cretácico, simulación numérica

\section{Introduction}

Rotational landslides are very frequent movements of slope worldwide, which largely affect cases of clayey materials with some degree of consolidation. The small landslides usually have a clearly defined circular morphology, especially if the materials that make up the slope are homogeneous.

A single rotational slide or slump is a "more or less rotational movement, about an axis that is parallel to the slope contours, involving shear displacement (sliding) along a concavely upward-curving failure surface, which is visible or may reasonably be inferred" (Varnes, 1978). The sliding surface need not be perfectly circular. An additional feature of a genuine rotational slide is the small degree of internal deformation of the displaced material, which distinguishes it from flow-like mass movement types, although sometimes soil slump material liquefies and transforms into a flow at its downslope end. Rotational mass movements can vary from terracettes with an area of only a few square meters to large complexes of several hectares. Great slopes (tens of meters) often produce complex movements. Sharpe (1938) called this form a slump-earth flow, and Varnes (1978) provided an idealized diagram showing the features of this complex slide, that usually affects engineering soils (debris, predominantly coarse; or earth, predominantly fine). For instance, La Conchita Landslide, Southern California occurred in 1995 is a good example of these complex (rotational- and flow-type) slides (Turner and Schuster, 1996; USGS, 2004).

Large rotational landslides are frequent on UK coastal cliffs and occasionally they affect layers of "weak rocks or strong soils' under saturated conditions. Stratigraphic series also includes rocky strata (gypsum, limestone, marl, sandstone). For instance, St Catherine's Point landslide, Isle of Wight, is a good example of a major bedding controlled slide (Hutchinson et al., 1991). The sliding surface is located in a thin clay layer, which is below sea level and the geological sequence is primarily mid to Lower Cretaceous (Bromhead and Ibsen, 2007). The Pico de Navas slump (Burgos, Spain) in the Iberian Cordillera can be compared in some way to the two models of landslides referred to above (earth slide-earth complex flow model of Varnes -1978-) and St. Catherine's Point landslide model (Hutchinson et al., 1991) as some of its features are similar.

Typical and very distinctive Utrillas facies materials are notably known for their extensive presence in the Ibe- rian Peninsula. Their characteristics have been the topic of copious research throughout the twentieth century. So we can quote references from its very first name by Tricalinos (1928) to Hanne (1930), Brinkmann (1931), Richter and Teichmuller (1933), Aguilar et al. (1971), Fallot and Bataller (1927), Canerot et al. (1982), Vilas et al. (1982), Floquet et al. (1982), Alonso (1981), among others, indicating the importance of studying of this type of formations.

The Utrillas facies which dates from the Albian (last unit of the Lower Cretaceous) is very common in the Cretaceous geological formations of mainland Spain. It mainly consists of sand, silt and clay minerals from the kaolin group and it shows a very characteristic variety of colours. Its extensive presence in the Iberian Peninsula, the constancy of its lithological characteristics, and the geotechnical behaviour of its deposits (which are clearly unfavourable to the stability of natural and artificial slopes), have made it infamous as a natural hazard and very problematical in terms of civil works constructions. Menéndez-Pidal (2006) lists more than thirty locations in Spain where difficulties arise in the execution and exploitation of large engineering works on this facies over the twentieth century.

It is highly significant that, in nearby terrains of this facies, serious problems have been caused due to instability, such as the case of the roadside cuttings of the Soria to Burgos highway, the Puerto del Mojón Pardo (Navaleno, Soria), and the Santander Mediterranean railway in the town of Navaleno (Soria) (some $15 \mathrm{~km}$ from Pico de Navas) when it was constructed in the nineteenth century. The grain size and mineralogy of the Utrillas facies in the Pico de Navas is almost the same. Deposits around Navas del Pinar were tested to estimate the fluidity capacity of the sands, by observing their behaviour in moulds loaded with water (bucket tests). These tests showed that, with little water, the material was extremely fluid and completely liquefied.

The probable causes of the Pico de Navas landslide should be related to the geomechanical features of the Utrillas facies (Albian, Lower Cretaceous) and specific hydrological conditions in the area that ought to facilitate the movement. In fact, numerous civil engineering constructions all along the Iberian Range have been affected by the potentially plastic behavior of these facies causing the failure of many slopes, mainly after rainfall periods (Menéndez-Pidal, 2006).

The mechanisms of rainfall induced landslides have been extensively studied and some of the conclusions assert that 


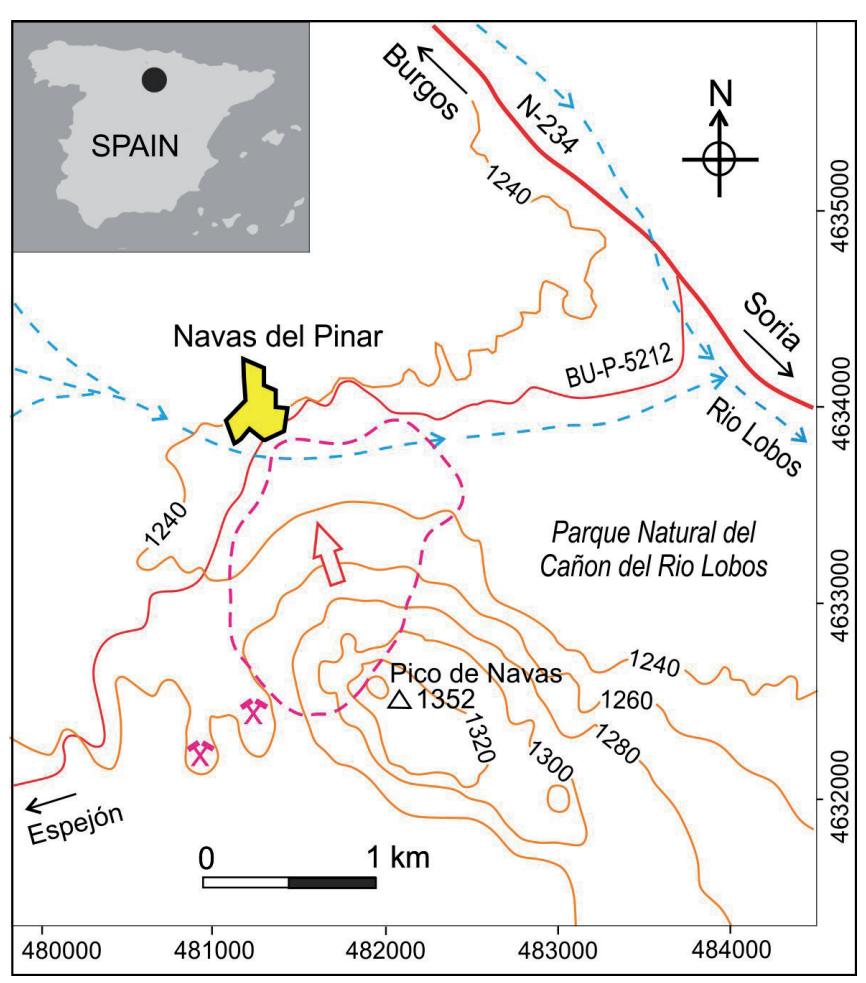

Fig. 1.- Location of the Pico de Navas Landslide (Burgos, Spain).

the amount of rain and weathering are the major factors predisposing a slope to failure (Iverson, 2000; Corominas, 2006; Msilimba and Holmes, 2010; Wang et al., 2002; Sassa et al., 2004; Guzzetti et al., 2008). Water infiltration is a significant triggering factor for slope failures around the world.

This paper is focus on four main objectives on the landslide: (1) geological and geomorphological features; (2) geomechanical characterization of the Utrillas facies (Albian, Lower Cretaceous) and interpretation of the hydrogeological conditions in the area around the slide; (3) study of the age and state of activity; (4) reconstruction of the original slope, analysis of its failure by mean of adequate numerical software (back analysis) in order to explain the possible causes and behavior of the movement.

\section{Methods}

A variety of methods and techniques have been used to study this landslide, which can be gathered as: desk work; field work and laboratory tests (Table 1). Firstly, desk work included: a previous review of scientific literature and maps related to the study area; geo-interpretation of aerial photographs; drawing of a geological map on scale 1:5000; stability analysis of the slope using FLAC program and interpretation of the whole data we have got. Secondly, field work consisted of: geological surveys for the recognition of the landslide area and the surroundings, including a description of geomorphologic features and the characterization of geological formations; an electrical geophysical survey (Shlumberger method) with 3 lines of about $150 \mathrm{~m}$ long and a boring survey with three boreholes (30-50 m long) with adequate sampling, SPT (Standard Penetration Test) and logging. In addition, 10 samples of silty and clayey sands of the Utrillas facies were specifically taken from the stable bedrock out the landslide (former kaolin quarry at Navas del Pinar). Besides, an archaeological survey was done in the area because the existence of an old Celtic-Iberian fortress on the top of the upper scarp. We recognized the archaeological remains of this ancient building and its characteristics to achieve its age, which have to be previous to the landslide age (Table 1)

And thirdly, laboratory tests were mainly focused on the geomechanical and mineralogical characterization of silty and clayey sand of the Utrillas facies, which corresponds to the main layer affected by the sliding surface (Table 1). They were: 10 Particle size tests of soils by sieve analysis (ASTM D-422-63, 2007) and 3 by ultrasound spectroscopy; 9 Standard tests for Liquid Limit, Plastic Limit and Plasticity Index of soils (ASTM D4318) and 4 Direct shear tests (Consolidated and drained) (BS 1377: Part 7:1990) which were performed without drainage to determine the internal angle of friction $(\varphi)$ and cohesion (c) of the materials involved in the movement. In addition, the mineralogy of the samples was studied using SEM (Scanning Electron Microscope) technique (Table1).

\section{Geological and Geomorphological Setting}

The Sierra de Navas (Burgos, Spain) forms part of the western end of the massif of the River Lobos Canyon, which comprises Cretaceous materials belonging to the northern zone of the Iberian Cordillera of northern and central Spain. The form of an inverted ship's prow is a characteristic shape of mountain promontories in the Cretaceous calcareous region of this sector (Pico Frentes, Peña

\begin{tabular}{ll} 
Type of work & Description \\
\hline \multirow{3}{*}{ Desk Work } & Aerial photographic image interpretation. \\
& Drawing of geological map (scale 1:5,000). \\
& Stability analysis with FLAC software. \\
\hline & 10 Particle-size analyses of soils. \\
& 3 Particle-size (ultrasound method). \\
& 9 Standard tests for Limit Liquid, Plastic Limit \\
Laboratory & and Plasticity Index of soils. \\
techniques and & 4 Determination of shear strength by direct shear \\
tests & box, CD test type (consolidated and drained). \\
& Mineralogical characterization by SEM method \\
& (Scanning Electron Microscope). \\
\hline Geological and geomorphological recognition \\
and mapping. \\
Electrical Geophysics (Shlumberger method) 3 \\
lines, 150 m long. \\
Boreholes (3), 30-50 m deep, SPT (Standard \\
Penetration Test), logging and sampling; 10 \\
Field Work \\
Archaecific samples from Utrillas sand.
\end{tabular}

Table 1.- Summary of methods and techniques used to study the Pico de Navas landslide. 


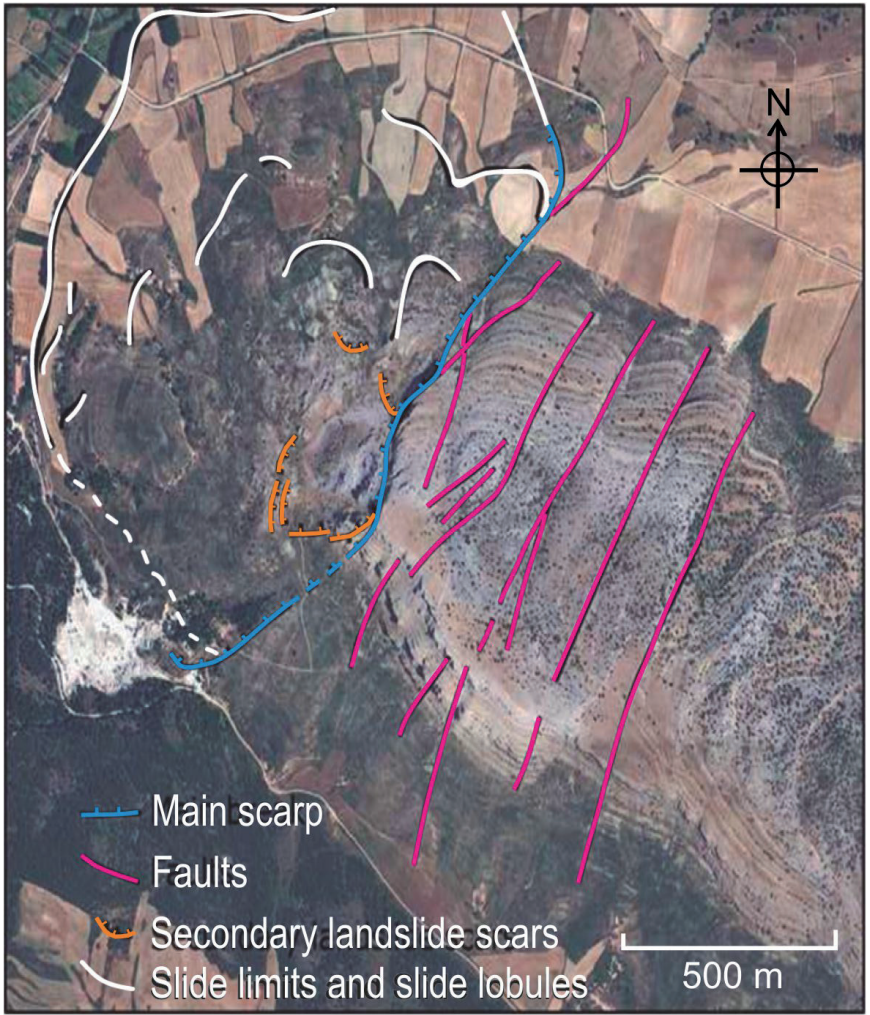

Fig. 2.- Geological features interpretation on an aerial photo of the Pico de Navas landslide and its surroundings.

Carazo, Sahuquillo de Alcázar, etc.). On these topographical high points the geological formations are well preserved and their stratigraphy well exposed. The Pico de Navas $(1,351$ $\mathrm{m}$ high) also shows this ship's prow form; being the last and highest peak of the Sierra de Navas, which has been affected by a massive gravitational landslide that displaced the northwestern end of the mountain (Figs. 1, 2).

The Cretaceous stratigraphic series that outcrops on the northern slopes of Sierra de Navas (Figs. 3 and 4) (bottom to top) consist of: (1) a layer of the Utrillas facies, comprising some $150 \mathrm{~m}$ of sand and gravel, with silt and clay minerals. Quartzarenites are predominant and kaolinite is abundant in their matrix. In fact, a kaolin mine at the base of the southern slope of Pico de Navas (Figs. 2, 3) was intensively exploited in the 1980s; (2) layer 15-30 m thick of very soft, yellowish-grey marls and clays of the Cenomanian; (3) layer $50 \mathrm{~m}$ thick of a hard marl limestone of the Turonian; and (4) massive grey limestone dated lower Coniacian-Santonian, $200 \mathrm{~m}$ thick, though in the Pico de Navas area only the lower 50 to $60 \mathrm{~m}$ are preserved. The geological structure of Pico de Navas corresponds to a syncline with W.NW-E.SE strike and $10^{\circ}$ E.SE. axis plunge. The syncline dips $10^{\circ}-15^{\circ}$ on its southern flank, giving rise to a scarp face, where the stratigraphic section described above comes from. All the resting outcrops of the fold correspond to its axial zone, which has a subhorizontal dip. Besides, the fold is crossed by a set of faults orientated N.NE-S.SW and separated about $150 \mathrm{~m}$ each fault to the other, and dipping $80-90^{\circ}$ towards the E. They are normal in type and give rise to small fault throws (Figs. 2, $3)$. The geometry of these structures determines that on the slope were predominantly present soft marls and clays (base of the Cretaceous) rather than the upper calcareous series, which are stronger and outcrops in the elevated NW block of the Pico de Navas fault.

\section{The Pico de Navas landslide}

\subsection{Landslide features and dimensions}

The features of this landslide are very conditioned by geological structures and by hydrological aspects. On one hand, it was developed on the axis zone of a syncline which also has a number of SW-NE parallel faults. And on the other hand, the hydrogeology had a direct influence on the movements of the slide, not only in the rupture surface but also in the erosion of the foot.

The area of the landslide is about $1.25 \mathrm{~km}$ wide plus $0.8 \mathrm{~km}$ long on average, i.e. $1 \mathrm{~km}^{2}$ in extension and it can be divided in three different zones (Figs. 3, 5): upper, middle and lower zones, which are about $0.15 ; 0.65$ and $0.2 \mathrm{~km}^{2}$ in extension, respectively.

(a) The upper zone has a main escarpment, 60-70 m high and about $1,600 \mathrm{~m}$ long, coincides superficially with a SW$\mathrm{NE}$ fault, corresponding to the main and upper scar of the landslide (Fig. 3). Nevertheless, the fault and the sliding surface have different traces once their surfaces are followed inside the rocky massif. The crown is very near to Pico de Navas peak (height $=1,351 \mathrm{~m}$ ) At the base of the escarpment there is a tilted rock mass composed of Turonian beds, broken into large and fragmented blocks due to the slide movement; (b) the middle zone comprises middle angle slopes $\left(10^{\circ}-15^{\circ}\right)$ with secondary scars and many slide lobes; and (c) the lower zone, though being the foot of the landslide deposit did not have an unique toe but a wide and semicircular apron, forming gentle and low angle slopes $\left(<5^{\circ}\right)$. Their semicircular contour is surrounded by a little stream, whose alluviums were invaded northward by the slide mass.

The main dimensions of the landslide are summarized in Table 2. The width and length of the displaced mass are 1,280 and $1,000 \mathrm{~m}$ respectively, the depth of the rupture surface is $153 \mathrm{~m}$ and the landslide achieve a total length of $1,030 \mathrm{~m}$.

\begin{tabular}{llcl} 
& Dimensions & (m) & Measurement type \\
\hline $\mathrm{W}_{\mathrm{d}}$ & Width of the displaced mass & 1,280 & direct (field) \\
$\mathrm{L}_{\mathrm{d}}$ & Length of the displaced mass & 1,000 & direct (field) \\
$\mathrm{D}_{\mathrm{d}}$ & Depth of the displaced mass & 187 & deduced (profile and modeling) \\
$\mathrm{H}_{\mathrm{d}}$ & Height of the displaced mass & 300 & deduced (profile and modeling) \\
\hline $\mathrm{W}_{\mathrm{r}}$ & Width of the rupture surface & 1,280 & direct (field, bore hole) \\
$\mathrm{L}_{\mathrm{r}}$ & Length of the rupture surface & 907 & deduced (profile) \\
$\mathrm{D}_{\mathrm{r}}$ & Depth of the rupture surface & 153 & deduced (profile) \\
$\mathrm{H}_{\mathrm{r}}$ & Height of the rupture surface & 320 & deduced (profile and modeling) \\
\hline $\mathrm{L}$ & Total length of the landslide & 1,030 & direct (field) \\
\hline
\end{tabular}

Table 2.- The Pico de Navas landslide main dimensions. Terminology from Dikau et al. (1996). 


\subsection{Characterization of the Utrillas facies layer}

\subsubsection{Basic properties}

The lower layer of the stratigraphic section of Pico de Navas is $100-150 \mathrm{~m}$ thick and is composed of silty and clayey sand of Albian age (Utrillas facies); it is the upper unit of the Lower Cretaceous (Fig. 4). Above, there are mainly marl and limestone layers of the Upper Cretaceous, which are harder and with more strength than the lower strata.

In the context of the Iberian Range, the Utrillas facies consist of various sedimentary materials: loose white sand, quartz gravel, purple, white or red clays, and locally clayey sands, rich in kaolin. The stratigraphic series of Pico de Navas consists of a succession of thin (decimetric) beds of these various lithologies, typical of Utrillas facies, although dominated by silt-clayey sands. The presence of kaoliniferous beds has to be pointed out because its strong influence in the geotechnical behaviour of this stratigraphic unit. The

\begin{tabular}{ccccc} 
& Sand & \multicolumn{3}{c}{ Fines } \\
\hline $\begin{array}{c}\text { Coarse } \\
\text { sand }\end{array}$ & $\begin{array}{c}\text { Medium } \\
\text { sand }\end{array}$ & $\begin{array}{c}\text { Fine } \\
\text { sand }\end{array}$ & Silt & Clay \\
\hline 2.32 & 8.44 & 12.16 & 71.06 & 6.02 \\
$(0-22)$ & $(0-59)$ & $(0-34)$ & $(5-89)$ & $(2-43)$ \\
\hline & 22.92 & & \multicolumn{2}{c}{77.08} \\
\hline
\end{tabular}

Soil description: silty sand with clay, $77 \%$ of fines content.

Table 3.- Particle size percentages (\%) on average of the Utrillas facies unit at Pico de Navas (interval of values in brackets), according to BS 5930:1999 classification.

natural Kaolin content varies from 1.25 to $10.46 \%$ (GalánHuertos and Martin-Vivaldi, 1974) meanwhile for mining exploitation of kaolin are necessary much bigger percentages. In fact, at the $\mathrm{SW}$ of the landslide there is an abandoned mine achieving $43 \%$ of Kaolinite (white zone in Figs. 2, 6). It is very close to the slip surface and is composed of many white beds very rich in Kaolinite.

Ten samples were taken in the area of the landslide representing the lithological variety within the layer with Utrillas

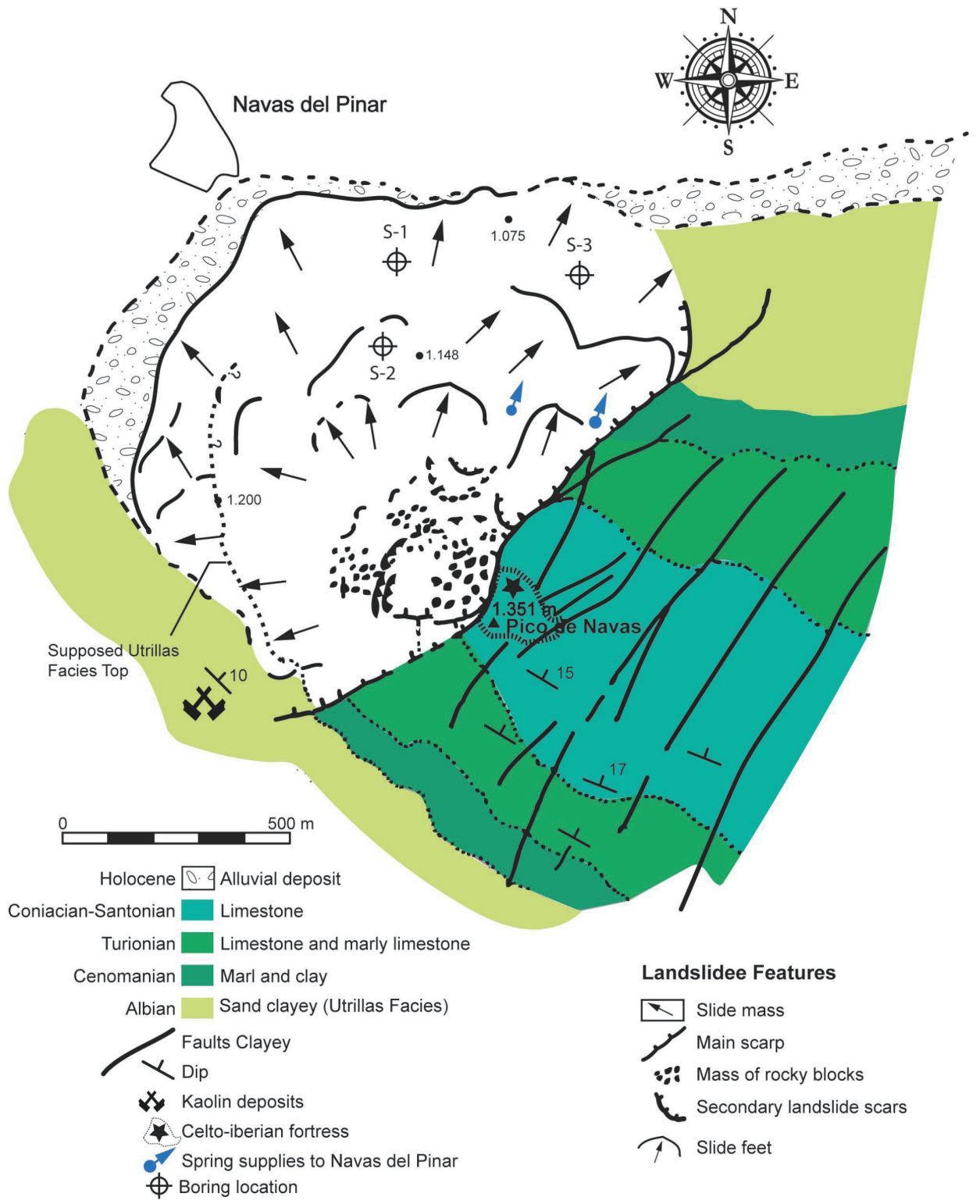

Fig. 3.- Geological Map of the Pico de Navas Landslide. Geological units in color. Note that even being general dip to NE, there is local and slightly dip variations collected into this figure. 


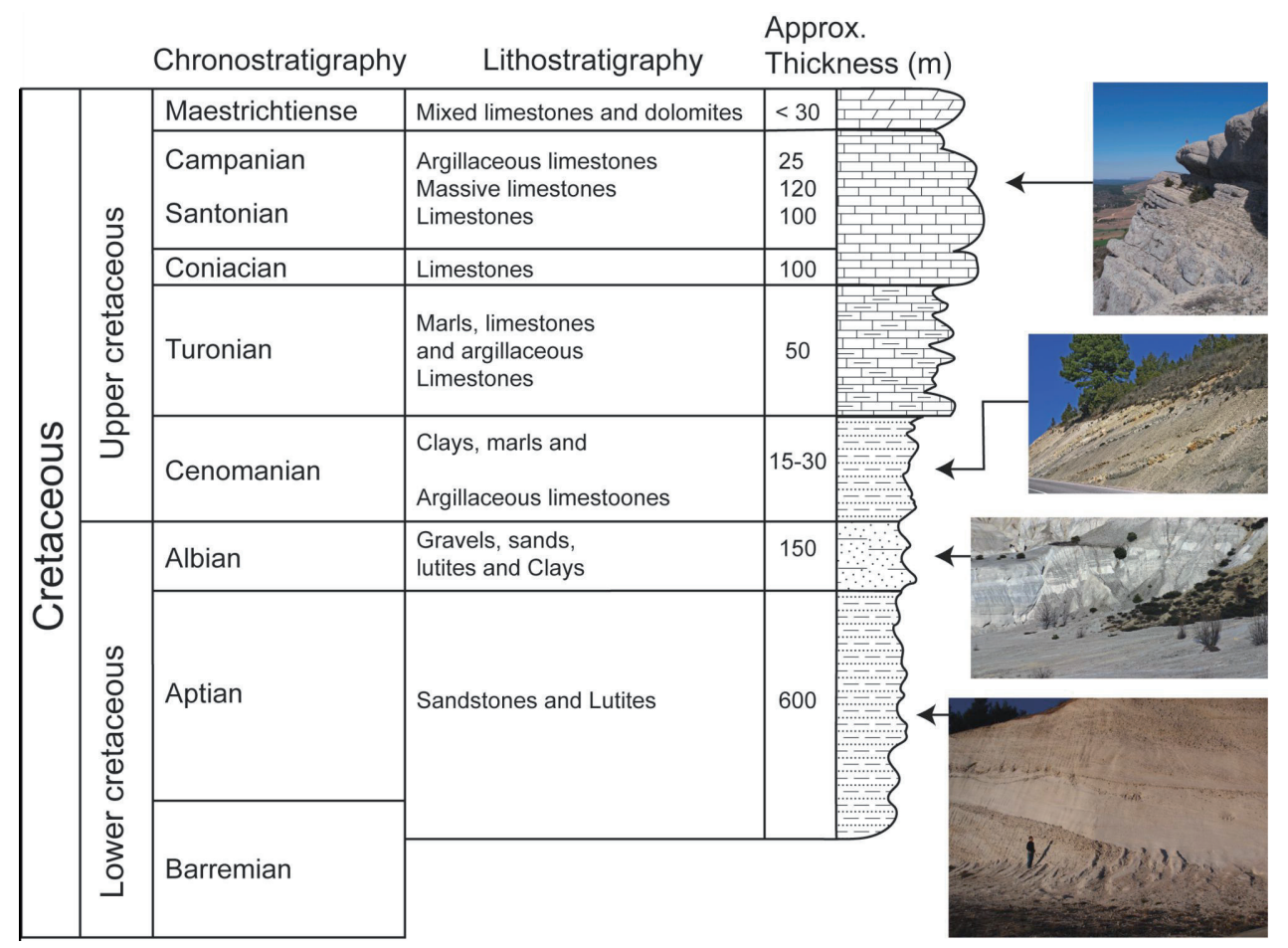

Fig. 4.- Stratigraphic sequence of Cretaceous units at Pico de Navas and stratigraphic section. Pictures on the left show outcrops of the main layers and their appearance.

facies. They are grouped into the following types: 5 sandy clay silt, gray to brown in colour; 3 white silty sand; 1 red sandy clay silt and other slightly rounded cemented gravel. These samples do not react to attack of hydrochloric acid, indicating low carbonate content, and do not contain organic matter (Table 1).

\subsubsection{Geotechnical index parameters: grain size and plasticity}

Using the soil classification methods for engineering purposes (e.g. USCS: Unified Soil Classification System) formations with Utrillas facies basically consist of a silty sand with some clay (Table 3). Fine particles content is high $(77.08 \%$ on average) but clay minerals content is generally low $(6.02 \%$ on average). Nevertheless in some cases it reaches $11 \%$, or even $43 \%$, when kaolinite content is high. In any case, there should be a considerable influence of fine particles $(>35 \%)$ on the geomechanical behaviour of this kind of soils.

Attending to standard plasticity parameters for fine soil classification (Table 4), the samples corresponds to CL-ML group (low plasticity clay and silt). Moreover, Liquidity in-

\begin{tabular}{lll} 
Symbol & Parameter & Values and classification \\
\hline LL & Liquid limit, \% & $16.50-32.50$ \\
PL & Plastic limit, \% & $15.26-25.25$ \\
PI & Plasticity index & $1.24-13.34$ \\
& Fine soil classification & CL-ML \\
W & Water content, \% & $2.3-17$ \\
LI & Liquidity index & $-0.61-1.4$ \\
& Consistency & Solid to plastic \\
A & Activity & $0.2-2.21$ \\
& Potential swelling & Low to very high \\
\hline
\end{tabular}

Table 4.- Plasticity parameters and fine soil classification, according to BS 1377:1999 standard. dex (LI) indicates solid to plastic consistency, depending on water content. Finally, activity values range within a wide data interval $(0.2-2.21)$, showing low $(\mathrm{A}<0.5)$ to high $(\mathrm{A}>1)$ potential swelling, which primarily depends on the content of clay in the soil.

\subsubsection{Geotechnical parameters}

Since in detail Utrillas facies unit consists of a succession of beds, decimetric to metric in thickness and of various lithologies, is difficult to obtain representative geotechnical parameters of the unit as a whole. Therefore, samples with four common lithologies were chosen (Table 5) and their geotechnical parameters were obtained by laboratory tests.

The unit weight ranges between 19 and $23 \mathrm{kN} / \mathrm{m}^{3}$; friction angles are $13^{\circ}$ to $38^{\circ}$ and the cohesion ranges between 10 and $48 \mathrm{kN} / \mathrm{m}^{2}$. For so wide range of values in the parameters is very difficult to establish a representative mean value. Nevertheless, it is likely that in wet condition and considering the pore pressure these parameters considerably decrease, resulting quite lower values. Such values have to be considered the effective ones (Table 5).

Furthermore, the layer sequence of limestones and marls outcropping above Utrillas unit has the following strength parameters: cohesion, $\mathrm{c}=10 \mathrm{kN} / \mathrm{m}^{2}$ and friction angle $\varphi=30^{\circ}$.

\subsubsection{Mineralogy and internal fabric (micro-structure)}

The Utrillas facies unit of Pico de Navas contains quartz minerals grains $(\approx 80 \%)$, feldspar $(\approx 10 \%)$ and clay minerals $(\leq 10 \%)$ according to Galán-Huertos and Martin-Vivaldi (1974) and corresponds to an arkosic sand with a variable content of silt and clay of kaolinite. The observation of this 


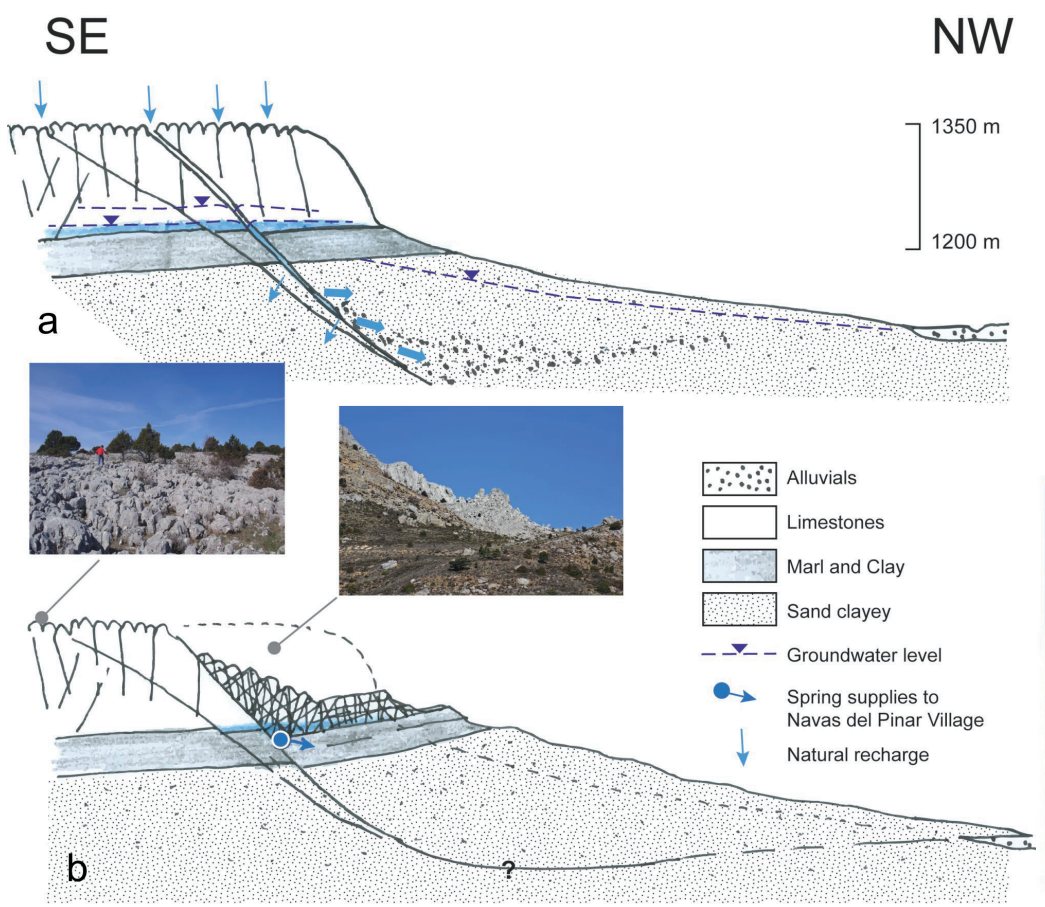

Fig. 5.- Geological main section of the landslide: (a) before the slide the Marl and Clay layer retained the water and facilitated its infilling into the fault; (b) after the rotational landslide water was concentrated in a specific zone (below the broken limestone unit and above the Marl and Clay unit) coinciding with the main spring in the area; (c) frontal general view from the North of Pico de Navas, showing the main scarp and the slide mass $\left(50 \times 10^{6} \mathrm{~m}^{3}\right.$ in volume). Note that even being general dip to NE, there is local and slightly dip variations collected into this figure.

C

material under the electron microscope shows that the clay fraction $(<2 \mu \mathrm{m})$ appears as a well crystallized kaolinite. About the $90 \%$ are heterometrical crystals (between 0.1 and $1 \mu \mathrm{m})$, generally with hexagonal shapes, although some crystals show rounded edges. The resting minerals are feldspars and micas somehow altered. This silty clayey sand have a specific internal constitution, because the fine grains stick together in clayey clumps over the terrigenous grains. The presence of these aggregates reaches $85-90 \%$ of the whole soil as SEM (Scanning Electron Microscopy) observation has shown (Fig. 7).

There are some studies on the behaviour of soils prone to form clumps or clods (Lambe, 1958; Daniel, 1984; Hermann and Elsbury, 1987; Benson and Daniel, 1990; Santiago, 2000) that shows most of the fluid flow through the clay soil occurs through the large pores between and around the clumps (macroporosity or secondary porosity) and not between the isolated clay particles (primary porosity or microporosity). Therefore, the relationship between the aggregates (abundance, size and density) and, between these and the voids of such aggregates, is crucial for the hydraulic conductivity of such materials.

Then, these pseudo-spherical clumps, even visible to the naked eye, form a specific structure in the Utrillas facies

\begin{tabular}{cccccc} 
Sample & Description & $\mathbf{\%}$ & $\boldsymbol{\gamma}\left(\mathbf{k N} / \mathbf{m}^{3}\right)$ & $\boldsymbol{\varphi}\left({ }^{\mathbf{0}}\right)$ & $\mathbf{c}(\mathbf{k P a})$ \\
\hline 4 & Silty sand & 20 & 20 & 27.5 & $<10$ \\
5 & Sandy gravel poorly cemented & 10 & 19 & 38 & 15 \\
6 & Sandy silt slightly clayey & 50 & 23 & 22 & 35 \\
7 & Clayey and sandy silt & 20 & 20 & 13 & 48 \\
\hline
\end{tabular}

Table 5.- Basic geotechnical parameters of the Utrillas unit at Pico de Navas (\%: approximate percentage of the presence of each soil type in the local stratigraphic section). sand, leaving the rest of the constituents (grains of quartz, feldspar and clay isolated particles) embedded within them.

The size of these aggregates is between 10 and $200 \mu \mathrm{m}$, being this value range within the limits of the silt fraction, fine sand and even fine and medium sand (Menendez-Pidal, 2006).

This feature of some clay particles, which generally tend to clump forming large aggregates, may be the cause of certain clayey beds behavior, despite having a general appearance of a sandy material. They can produce unexpected changes of plasticity and thus it produces deformability, even with a small amount of water within its structure.

\subsection{Age of the Movement and state of activity}

The morphology of the slide deposit seems to be well preserved (Figs. 2, 3, 5) but, as far as we know, there was not any significant activity over the last few hundred years. The patchwork of fields over the lower part of the landslide date at least as far back as the tenth century, and no historic tradition amongst the local inhabitants refers to instabilities of the ground. The water supply for Navas del Pinar, for example, which crosses the middle and lower portions of the landslide, has never been cut as a result of ground deformation. The rocky outcrop of the head scarp has been altered, but only the chaos of blocks in the central part of the crown (Peña del Fraile) seems to be fresher and less colonized by lichen, suggesting that there might still be a very slow background movement.

On the other hand, the oldest pottery items found on the surface date from the Iron Age. Nevertheless, there are three facts that can be taken as more certain: 


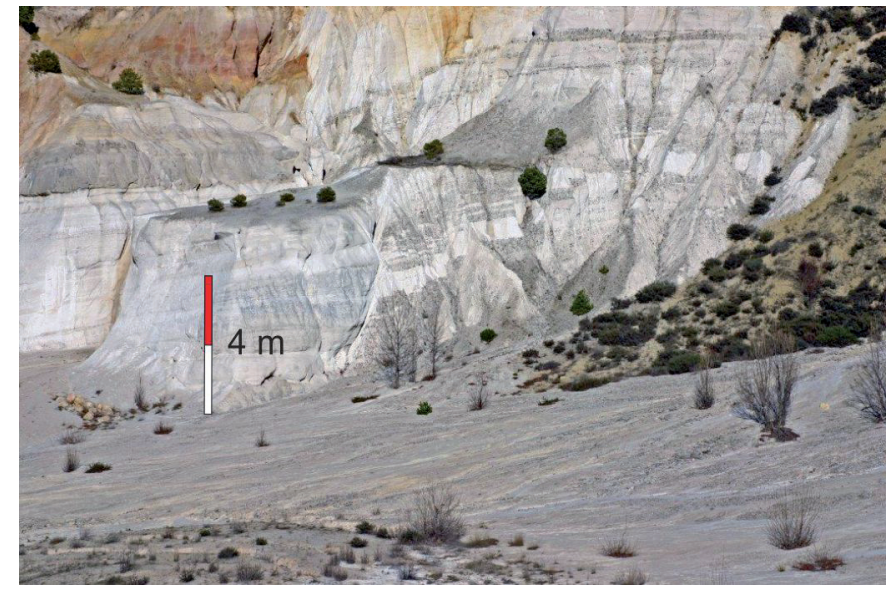

Fig. 6.- Albian layer (Utrillas facies) densely fractured at the SW lateral zone of the slide mass. White beds reach more than $40 \%$ of Kaolinite in content.

(1) The movement displaced the Navas stream that flows around the base of the mountain, narrowing its alluvial plain. Like all river deposits in this area, the alluvium below the lowest terrace can be dated to the Holocene. However, as commented above, at the foot of the landslide, subsequent erosion by the stream has occurred, though it is very blurred due to ploughing of the fields. The difficulty in distinguishing some sediment from others dissuaded us from opening trial pits to take samples of organic material for dating, since it could confuse more than clarify. Thus, it can be taken that the movement occurred during the Holocene.

(2) It is not pointing any deposit of the Chalcolithic (Bronze Age) on landslide formation, although this is very common in the surrounding area as there is lithic industry of this period (Abásolo and García Rozas, 1980).

(3) At the summit of the Pico de Navas there is an Iron Age hillfort, situated precisely to take advantage of the natural barrier to the NW formed by the scarp of the landslide. The more accessible SW edge still conserves two walled alignments, one of which is linked to a spectacular limestone karren, which served as a defensive device (as in Celtic hillforts in Iberia). Since the archaeological site dates from the fourth or fifth century $\mathrm{BC}$, we can be sure that the movement had already taken place by this time.

Landslide treads the Holocene alluvial deposit of the stream; therefore it is dated later than 10,000 BC. Thus, in principle, the landslide occurred between the Neolithic $(5,000 \mathrm{BC}$ to the Iron Age). It must not be a very ancient movement as it also retains its fresh geomorphology.

According to the classification of Dikau et al. (1996) on the states of activity of landslides, Pico de Navas slide can be considered inactive, being an abandoned landslide ("inactive landslide which is no longer affected by its original causes") or even a relict landslide ("inactive landslide which developed under climatic or geomorphological conditions considerably different from those at present").

\subsection{Back analysis and evolution}

Based on the present day topography of the landslip and the surrounding landforms we have done a hypothetical reconstruction of the topography previous to the landslide. This antecedent geometry is shown in Figure 5a (main cross section). If a stability analysis of the ancient geometric dimension is performed, the conditions at the onset of the landslide can be inferred.

Since the current topography is known (Fig. 5a, b), it is also possible to recreate the original topography before landslide and obtain an accurate prediction in the initial situation of instability to reality by a numerical modeling using the geotechnical calculation software FLAC. Figure 8 shows a model with the main cross section of the topography of the situation before the landslide which has been introduced in the calculation software.

The main material is a sequence of limestones and marls above Utrillas facies layer as obtained from the geological section described above (Figs. 4 and 5a). All the involved materials are modelled as Mohr-Coulomb type; in the case of Utrillas facies unit, the parameters are obtained from available tests presented in Table 5. It is intended to perform a geomechanical modeling only at the initial moment of sliding; therefore should be chosen parameters of Mohr-Coulomb failure criterion corresponding to that instant. An average value of the density equal to $21 \mathrm{kN} / \mathrm{m}^{3}$ is adopted. It is considered a null value of cohesion to represent the initial state of the creep process in the situation of initial instability (since the cohesive behavior is limited by the coarser fraction); meanwhile, the frictional behavior is mainly marked by fines fraction which is predominant in Utrillas facies unit, so that their average value of friction angle equal to $18^{\circ}$ is chosen. An elastic modulus of $10 \mathrm{MPa}$ for both materials and Poisson's ratio of 0.3 is considered; however, as is well known generally for such problems, the deformation moduli do not affect the value of the safety factor. These parameters are given in Table 6 .

For the boundary conditions, horizontal constraints for laterals contours and both horizontal and vertical constraints for the lower boundary of the model are considered.

The position of the fault has been incorporated into the model as shown in figure 8 . The model includes an interface with residual friction angle equal to one third of the friction angle of upper material of limestones and marls $\left(10^{\circ}\right)$.

For calculation purposes, water table has been calculated to level of 1,285 m for strict equilibrium. First of all, initial stresses under static conditions (only under vertical gravity loading) are calculated, considering the water pressure caused by the water table (Fig. 9), as previously described. The estimation of horizontal effective stresses has been performed with Jaky's formula, since, even if this is clearly not a horizontal layered soil configuration, it can be considered accurate enough for this estimation. As a conclusion of this 

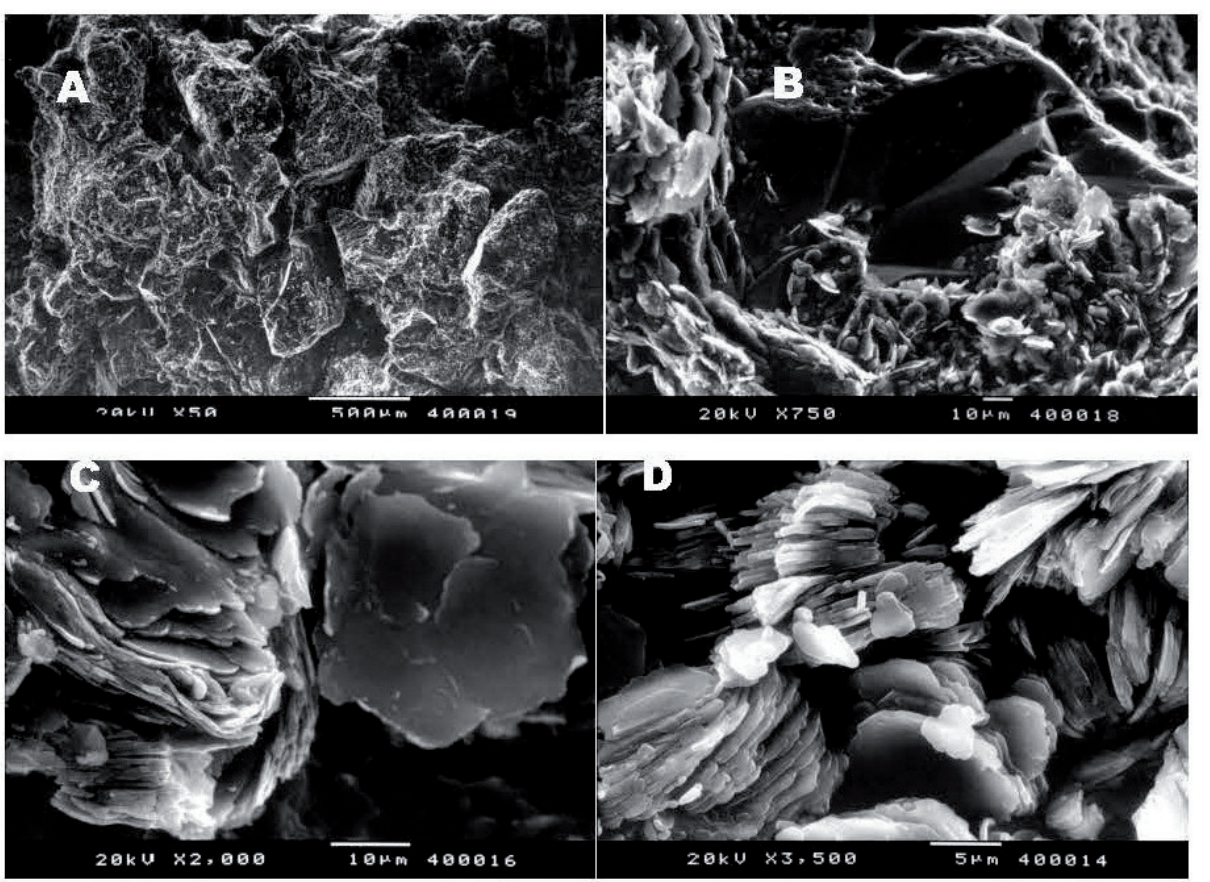

Fig. 7.- SEM (Scanning Electron Microscopy) images of a clayey and silty sand from the Utrillas facies unit. (A) General view (x50) showing little matrix among sand grains but very abundant on their surfaces. (B) Detailed view (x750) of a quartz grain almost embedded in lamellar kaolinite particles with a large lateral development and medium thick size. Note the scarce presence of voids between the grains and particles constituting the matrix. (C) Above image in more detail (x2.000): well developed lamellar particles of kaolinite. Note the absence of impurities and their pseudo-hexagonal shaped crystals. (D) Piles of kaolinite (x3.500), showing voids among kaolinite aggregates. calculation, stability of this slope under static conditions have been found.

For proper back analysis, it has performed a sensitivity analysis by varying the strength parameters of the two geotechnical units and the position of the water table (Table 7). From this analysis, the considered situation of strict equilibrium can be identified.

The obtained 2D failure surface is the one depicted in figure 10, which fits the field observations. In this way, the current geometric situation is analysed. The stability is calculated before slippage occurs using the geomechanical parameters tested. This yields a surface with a safety factor close to 1,000 , which indicates the strict equilibrium of the mass considered in this calculation.

In addition, it is intended to represent the correct direction of movement of the landslide for the final equilibrium situation. To do this, 3D model using geotechnical calculation software FLAC 3D, has been implemented. Geotechnical properties of both materials shown in Table 6 were considered. It has simplified model considering the fault as a boundary where the failure is initiated and water table with the maximum level of $1285 \mathrm{~m}$ indicated above is adjusted (Fig. 11). Figure 12 shows the direction of movement of the failure surface in the 3D model.

The Pico de Navas landslide has all the characteristics to classify it as a large magnitude rotational movement (Varnes, 1978; Corominas, 1989; Cruden and Varnes, 1996), affecting more than $50 \cdot 10^{6} \mathrm{~m}^{3}$ earth. The main rupture of the rotation affected the Utrillas sands. However, the rotational movement also involved the rest of the overlying stratigraphic sequence of limestone and marls, which is $150 \mathrm{~m}$ thick, and clays and marls, about $30 \mathrm{~m}$ thick. They underwent a series of expansion changes in the existing stratigraphic context, meant that the weight of the limestones would deform the underlying

\begin{tabular}{|c|c|c|c|c|c|}
\hline Material & $\begin{array}{c}\text { Apparent } \\
\text { specific } \\
\text { weight } \\
\left(\mathrm{kN} / \mathbf{m}^{3}\right)\end{array}$ & $\begin{array}{c}\text { Cohesion } \\
\left(\mathrm{kN} / \mathrm{m}^{2}\right)\end{array}$ & $\begin{array}{l}\text { Friction } \\
\text { angle }\left(^{\circ}\right)\end{array}$ & $\begin{array}{c}\text { Elastic } \\
\text { modulus } \\
(\mathrm{MPa})\end{array}$ & $\begin{array}{c}\text { Poisson's } \\
\text { ratio }\end{array}$ \\
\hline $\begin{array}{c}\text { Sequence of } \\
\text { limestones and } \\
\text { marls }\end{array}$ & 25 & 10 & 30 & 10 & 0.3 \\
\hline $\begin{array}{l}\text { Utrillas } \\
\text { facies }\end{array}$ & 21 & 0 & 18 & 10 & 0.3 \\
\hline
\end{tabular}

Table 6.- Geotechnical parameters of the sequence of limestones and marls and Utrillas facies.

\begin{tabular}{ccccc} 
& & \multicolumn{3}{c}{$\begin{array}{c}\text { Maximum level } \\
\text { of water table (m) }\end{array}$} \\
\hline $\begin{array}{c}\text { Utrillas facies: } \\
\begin{array}{c}\text { Friction angle } \\
\left(\mathbf{o}^{\mathbf{}}\right)\end{array}\end{array}$ & $\begin{array}{c}\text { Limestones and } \\
\text { marls: Cohesion } \\
\left(\mathbf{k N} / \mathbf{m}^{2}\right)\end{array}$ & $\mathbf{1 2 9 0}$ & $\mathbf{1 2 8 5}$ & $\mathbf{1 2 7 5}$ \\
\hline \multirow{2}{*}{16} & 7.5 & 0.87 & 0.91 & 0.96 \\
& 10 & 0.90 & 0.92 & 0.98 \\
& 12.5 & 0.91 & 0.93 & 0.99 \\
\hline \multirow{2}{*}{18} & 7.5 & 0.93 & 0.97 & 1.04 \\
& 10 & 0.96 & 1.00 & 1.07 \\
& 12.5 & 0.99 & 1.02 & 1.08 \\
\hline & 7.5 & 1.01 & 1.05 & 1.12 \\
& 10 & 1.03 & 1.07 & 1.15 \\
& 12.5 & 1.06 & 1.10 & 1.18 \\
\hline
\end{tabular}

Table 7.- Sensitivity analysis. Safety factors in the 2D model.

beds, causing them to lose their resistance and provoking an extrusion or radial plastic flow over the open boundary and into the valley at the base of the mountain. Even so, the movement was also conditioned by the dip of the strata towards the NW (Note that even being general dip to NE, there is local and slightly dip variations collected into figures 3 and 5). The extrusion of the marls must have been enhanced by 


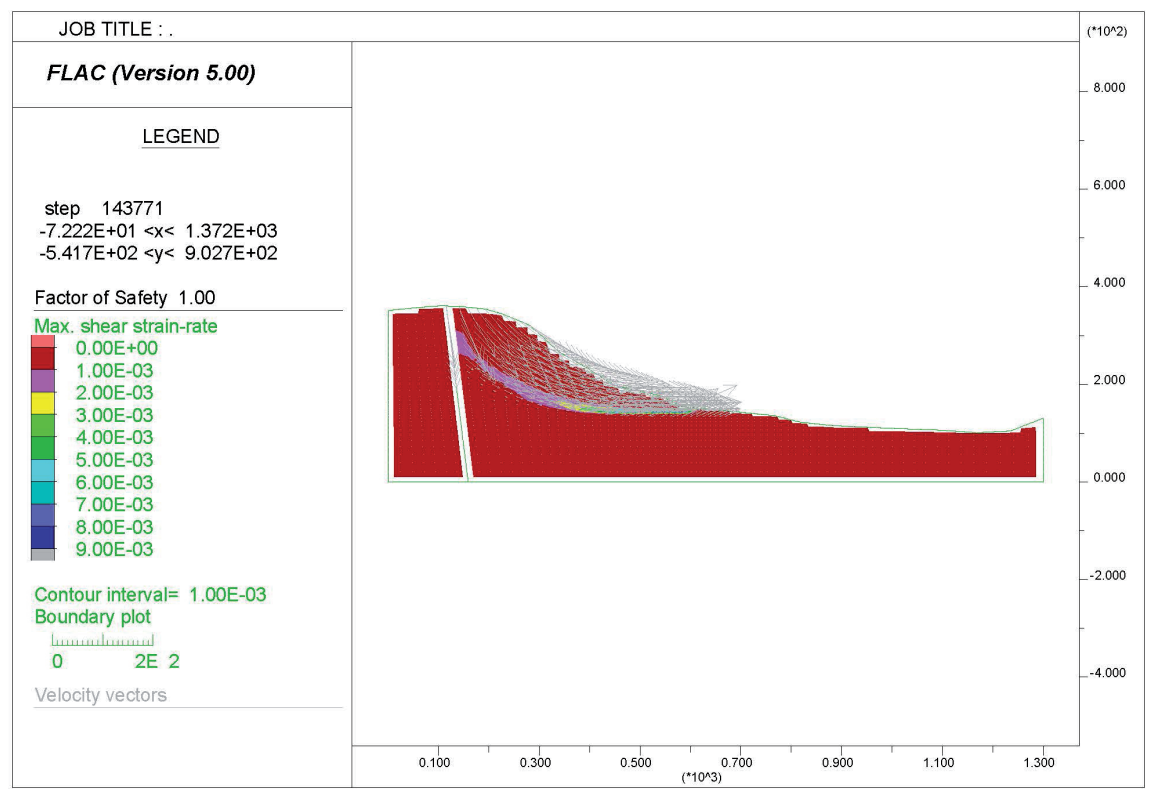

Fig. 8.- Initial geometrical model considered for the numerical simulation.

Fig. 9.- Water pressure caused by the water table for the numerical simulation.

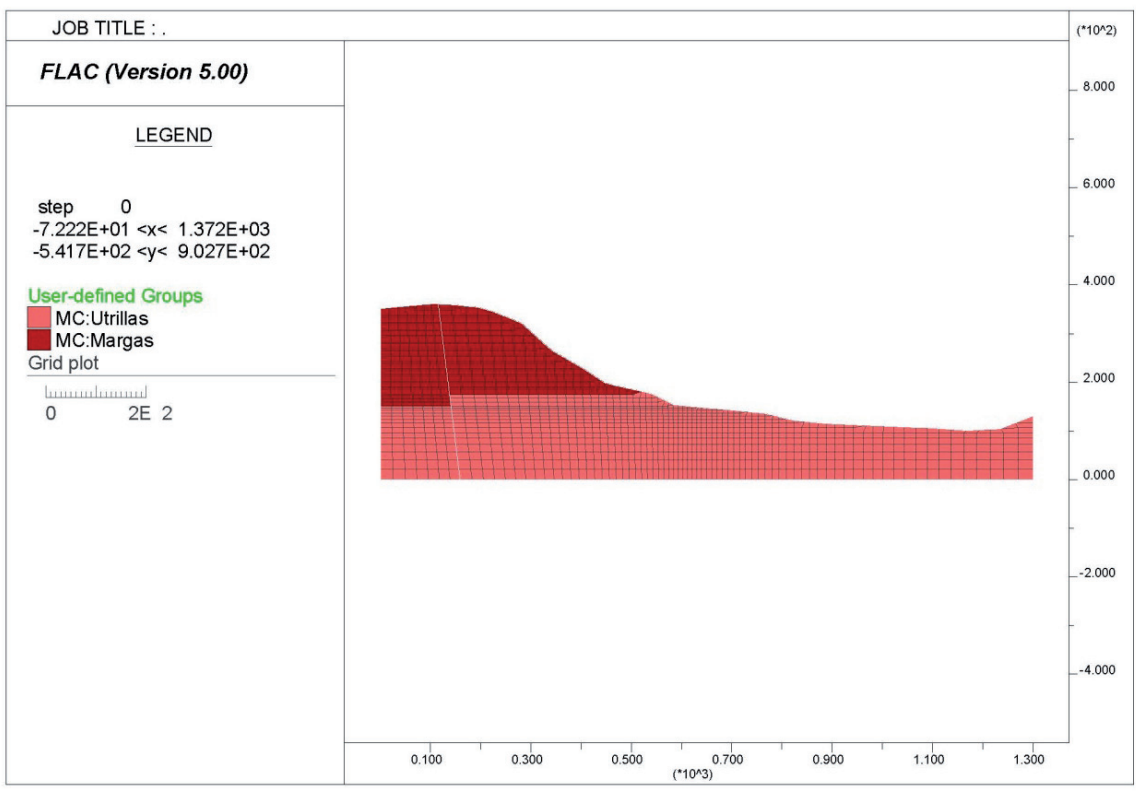

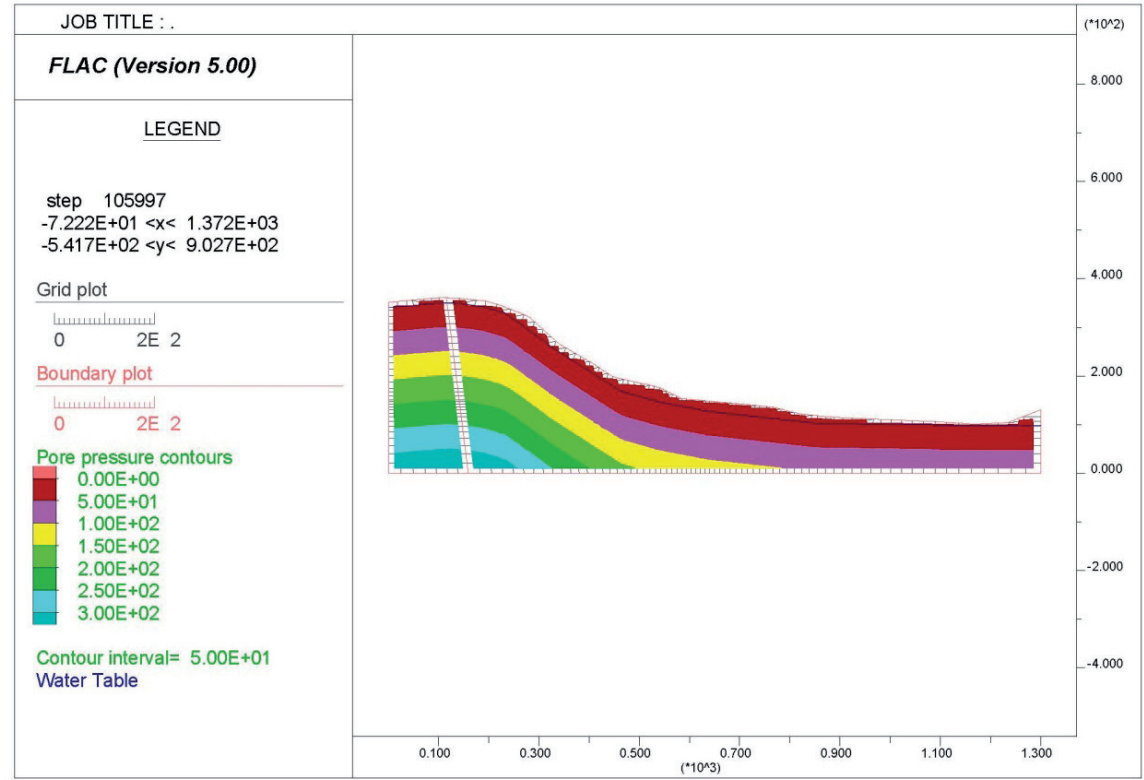

Fig. 10.- Sliding surface obtained with the numerical simulation with the water table as estimated in figure 9. 
wet conditions, since the permeable-impermeable contact lies within this layer. Today, these marls and clays still act as the impermeable base, leading to the existence of two springs halfway up the mountain, which drain the neoformation aquifer created in the fragmented mass of limestones and marly limestones, and which supply the village of Navas del Pinar. Based on a survey of the geology of the landslide, it was easily confirmed that the clay and marl beds are thicker towards the outer edge in comparison with their initial thickness, as is shown in figure 4. But this layer was not completely laminated, and so it continues to act as the impermeable base of the overlying carbonate aquifer.

A basal subhorizontal shear surface is well defined from borehole logs. It coincides with the Utrillas facies unit and reaches as far as the base of the mountain, to the Arroyo de Navas (Navas stream).

\section{Conditioning factors and possible causes}

There are minor factors contributing to the instability of the slopes of Pico de Navas, as is its height and relatively steep slope, its shady orientation that increases and retains more moisture from the ground, or the slight dip of the layers to the north. However, there are other determining factors that explain the mechanism and evolution of this sliding. A crucial role is due to the presence of major fractures and the action of water infiltration through them, the lithology of Utrillas facies and hydrogeology of the massif.

This landslide has been strongly conditioned by the existing intense fracturing, being the faults situated externally (of whole family of parallel faults that cross the massif) which have controlled the formation of the tension great crack on the top of the landslide. These faults, which affect the whole stratigraphic series, dipping to the north implies that the tensile strength to form the main breakage on the top was already overcome. The orientation and dip of this major discontinuity is also favorable to slip outwards. The fault affects sands and clays underlying Utrillas facies, breaking and pugging the clay aggregates, thereby decreasing the strength properties.

The hydro-stratigraphic characteristics of terrains that appear in the rock mass are fairly well defined: limestone and dolostone belonging to the Coniacian, Santonian and Campanian units which are highly permeable and are the main karstic aquifers of the region. In contrast, marl, marly limestone and Cenomanian and Turonian clays are quite impermeable and form the basis of carbonate aquifers. Most of the large springs in the region, as the spring of La Galiana $(2,000$ $1 / \mathrm{s})$ or Fuentona Muriel $(1,000 \mathrm{l} / \mathrm{s})$, are in the contact between these two lithologies of very contrasted permeability. The sands of Utrillas facies of the Albian, have intergranular permeability with mean or low values in function of clay content and degree of cementation.

Carbonated outcrops of the Pico de Navas have a high infiltration capacity because they are intensely karstified in the surface. There are areas of very dense and developed karren as this mountain has been exposed to erosion since at least the end of the Tertiary, that is, for at least five million years. Karrenfeld acquire such development on the top of the mountain, which were used as natural defenses by way of "Chevauxde-frise" of the Celtic and Celtiberic culture against enemy cavalry in the hillfort of the Iron Age, which stands at the summit of the mountain (Fig. 5).These karrenfeld and joints are responsible of meteoric infiltration processes whose water flows through the major faults back down, allowing cross impermeable layers of clay and silt and communicate with kaolin sands of Utrillas. Faults hydraulically communicate the three groups of described hydro-stratigraphic units in the vertical and stimulate or have stimulated in the case of tensile crack of sliding, the almost permanent saturation of low permeability levels placed under the same and the decreasing of the resistance values of the rock.

There is an important hydrogeological aspect that should be taken into account. It is the big swing that often have groundwater levels in these calcareous aquifers, so that is usual that exceed of 30 to $40 \mathrm{~m}$ in a few days. This has been observed in piezometers and surveys (Sanz, 1999), and in typical troppleins presence of numerous springs. For example, the spring of the birth of the river Mazos (about $50 \mathrm{l} / \mathrm{s}$ average flow) arises from a fault and when the water level rises more than $40 \mathrm{~m}$, and overflow appears (Sanz, 1999).

The current climate type is Mediterranean, with a mean annual precipitation of $750 \mathrm{~mm}$ and mean annual temperature of $10^{\circ} \mathrm{C}$. The landslide would have occurred during the Recent or Middle Holocene. According to numerous climate and vegetation studies for this region (for example, in the $\mathrm{Si}$ erra de Neila, some $30 \mathrm{~km}$ distant (Ruiz-Zapata et al., 2002), three separate periods of wet climate have been identified and dated to around 8,500 BP (Before Present), 5,000-4,500 BP, and between 2,760-2,500 BP.

Another cause to note is the abundance of kaolin in the Utrillas facies in this area of the Iberian Cordillera, and the Pico de Navas in particular, where a deposit that has been profitable exploite was located, although for years this abandoned for environmental reasons (is a Natural Park). On this site, representative of the stratigraphy of Pico de Navas, the kaolin clay layers are abundant and have several times more than $2 \mathrm{~m}$ thick, constituting the bulk of the stratigraphic unit of Utrillas facies.

From the beginning the water infiltrated into the rock mass through the pre-existing main fault favoring the gradual weathering of surrounding materials to the discontinuity, i.e. the Turonian marls and clays and the Albian sands.

Although, the failure mechanism is not progressive ( $\mathrm{Ji}$ menez-Salas, 1984), it is quite similar. In the progressive failure, as its name suggests, the tension crack is created from an existing fracture that only affects the top level. Then this progresses down through the action of weathering of water that enters the fracture. In our case, it was based on the ex- 


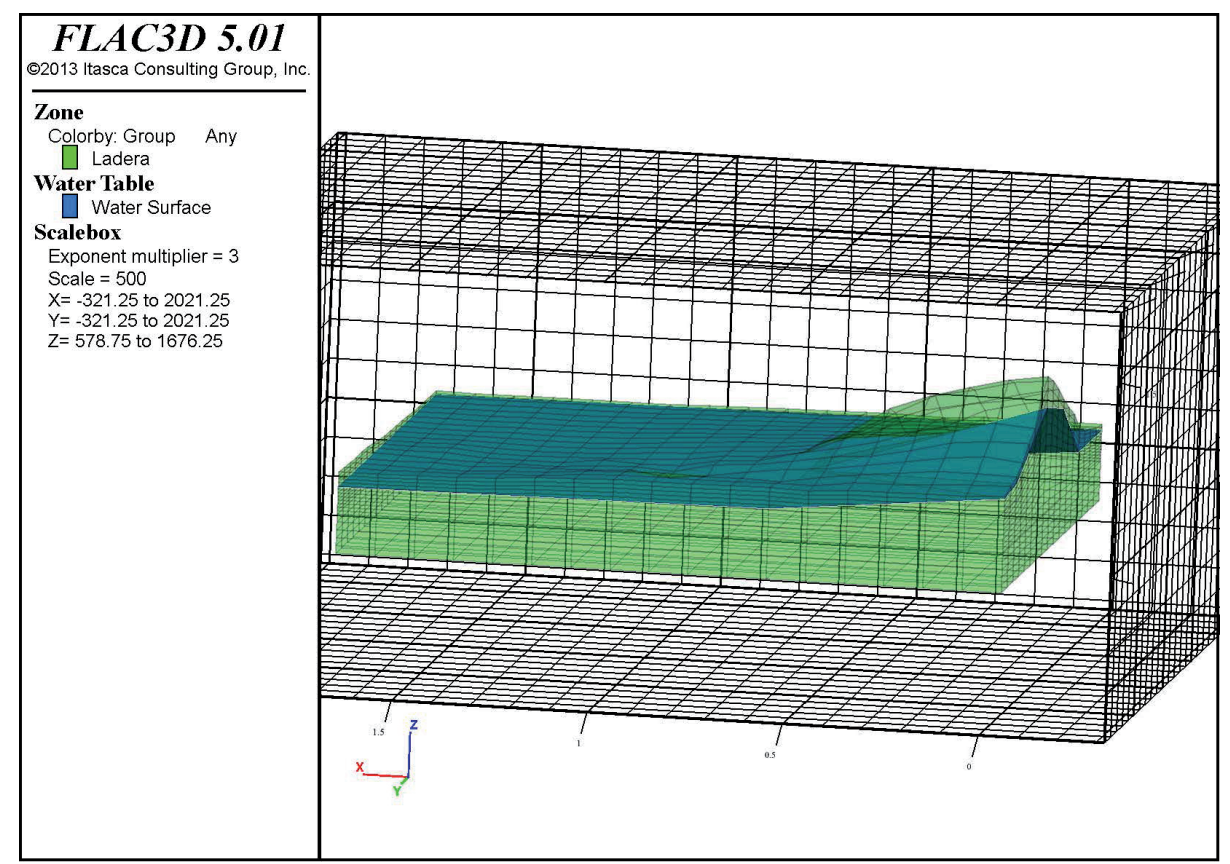

Fig. 11.- Initial geometrical model and estimation of the water table for the 3D simulation.

Fig. 12.- Direction of movement of the Sliding surface obtained with the 3D simulation with the water table as estimated in figure 10.

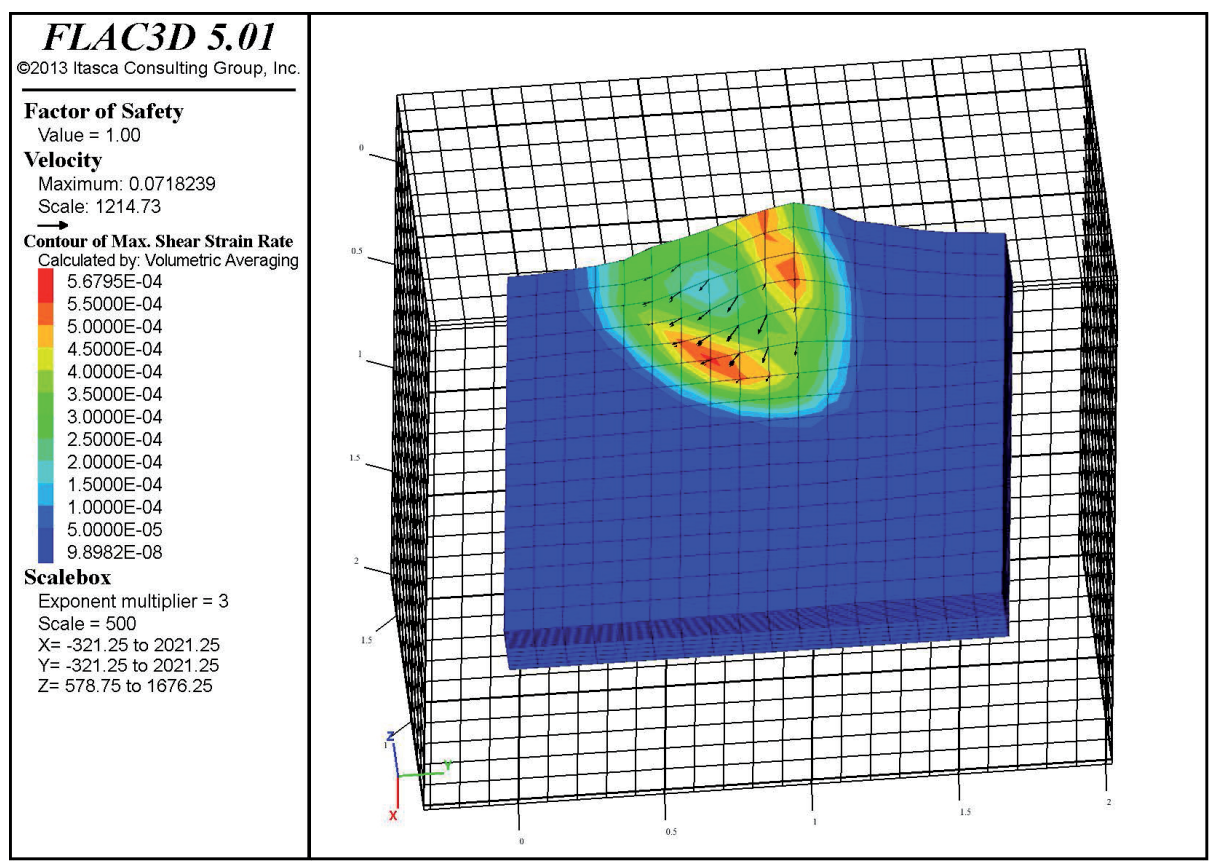

istence of a fault running through the whole stratigraphic series, but the action of water undoubtedly influenced the loss of strength of the fault, and the tendency to form a potential rupture surface at the Utrillas in the base level of the slope. A sufficient approximation of the slope profile at a given time, and / or the hydraulic load that could be at the fault in any wet season, is what could finally trigger the landslide.

The movement began on the upper part of the mountain, with the opening of a rupture surface which largely coincided with and pulled away from the upper, vertical portion of the pre-exisiting fault, but which formed another curved fault at great depth. The dip of this curved fault becomes horizontal in the Utrillas facies, along the basal contour of the mountain. This fault produced a movement comparable to a nor- mal fault, lowering the NE block by some $80 \mathrm{~m}$. There are other traction fissures at the head, subparallel to the principal fault and which, together with the chaotic aspect of this part of the landslide, give the impression of a young landform, even though the movement is very ancient. The flow of liquefied mud from the clay and marl layer at the middle and base of the landslide invaded the other slopes, as well as the Holocene alluvial plain, in the form of deformed, elongate lobes. These lobes formed a clayey blanket 1 to $3 \mathrm{~m}$ thick over the sands of the Utrillas facies (Fig. 3).

The Utrillas facies includes beds of fine sands with an abundant silty and kaoliniferous matrix. This confers high porosity between the particles, including the clayey aggregates; it also means that there is no internal cementation to bond the 
particles together. Thus, it is understood that the structure of the Utrillas facies confers extreme instability and fluidity to the entire mass when presented with large quantities and head pressure of water.

Alternatively, it would easy to think that the increased fluidity of the materials was caused by an increase in water pressure resulting from an earthquake, whose dynamic action would have been amplified by the fault. However, from a seismic point of view, the zone is very stable.

\section{Conclusions}

\subsection{Dimensions and possible age}

The Pico de Navas landslide was a large-magnitude rotational movement, affecting $1 \mathrm{~km}^{2}$ in extension and $50 \times 10^{6} \mathrm{~m}^{3}$ of hard to soft rocks. The displaced mass is $1,280 \mathrm{~m}$ wide, $1,000 \mathrm{~m}$ long and $300 \mathrm{~m}$ high. It certainly occurred before the 5th Century BC, probably during the Middle-Late Holocene and possibly during a wet climate period in the region, i.e. ca 8,500 BP; 5,000-4,500 BP or 2,760-2,500 BP (Ruiz-Zapata et al., 2002).

\subsection{Slide mechanism}

The movement began on the upper part of the mountainside, where an important vertical fault cause a principal rupture surface that crossed the entire stratigraphic series of the Upper Cretaceous, $300 \mathrm{~m}$ in thickness. It extended as far as the base of the mountain, where it curved towards the horizontal, following the sillty and clayey sand beds of the Utrillas facies. They turn plastic and fluid where they lay below the water table. The movement of the down faulted block, as in a normal fault, caused a slump of some $80 \mathrm{~m}$, as well as the total fragmentation of the overlying series of limestone and marl limestone, and the extrusion of the underlying layer of plastic marls and clays due to the weight of the overlying rocks. It caused a generalized slow movement of a large body of rocks towards the north-west, clearly conditioned by the general dip of the massif. As far as we know, only one large movement occurred, and no different stages are morphologically distinguishable. In relation to its state of activity Nowadays, Pico de Navas landslide is considered as inactive, being an abandoned or even a relict landslide.

\subsection{Possible causes}

As the Arroyo de Navas stream that flows at the base of the mountain nearly produced a significant erosive action, it was not an effective cause on the movement. As mentioned above, its origin is possible linked to a period of wetter climate than today. In any case, a rise of the water table and the natural water content of the terrain were necessary to cause the displacement. A period with high increase in rainfall or a drop in temperature could have also increased natural water recharge into the massif.

\subsection{A specific study case}

The large size of the Pico de Navas landslide $\left(1 \mathrm{~km}^{2}\right.$ in extent and $50 \times 10^{6} \mathrm{~m}^{3}$ in volume) allow be compared to other large complex landslide of literature, the type rock slide earth flow in the terminology of Varnes (1978) and Cruden and Varnes (1996).

However, the geological context and hydrogeological conditions that occurred in this slide are specific, allowing to consider this slide a case study apart.

The distinctive elements are: (a) a rock mass with a potent upper zone of limestone $(300 \mathrm{~m})$, failed and partially dissolved; (b) that after the movement, rotation and intense fragmentation occurs in blocks; (c) intermediate zone of marl and clay $(<30 \mathrm{~m})$, which is essentially impermeable and allowed the existence of a perched water level before the movement, facilitating the entry of water into the upper breaking surface and saturation conditions in the lower regions; (d) a lower zone of silty sand and kaolinite clay (Utrillas facies) $(150 \mathrm{~m})$, sometimes with a high percentage of kaolinite $(40 \%)$, which suffered a fluidification (or solifluction), facilitating the continuity of the breaking surface which happens to be curved to be flat and horizontal.

Numerical simulation of the conditions of stability has supported the possibility that the original hypothetical conditions occurred (topography, geomechanical and hydrogeological conditions).

\section{References}

Abásolo, J.A., García Rozas, R. (1980): Catálogo arqueológico de la provincia de Burgos. Partido Judicial de Salas de los Infantes, Burgos, pp. 48-49.

Aguilar, M., Ramírez, J., Riba, O. (1971): Algunas precisiones sobre la sedimentación y paleoecología del Cretácico Inferior de la zona de Utrillas-Villarroya de los Pinares (Teruel). Estudios Geológicos 27, 497-512.

Alonso, A. (1981): El Cretácico de la provincia de Segovia (borde $N$ del Sistema Central). Seminarios de Estratigrafía: Serie Monografías 7. Universidad Complutense de Madrid, Madrid, $271 \mathrm{p}$.

ASTM D422-63 (2007): Standard Test Method for Particle-Size Analysis of Soils. American Society for testing and materials, Philadelphia.

ASTM D4318-05 (2005): Standard Test Methods for Liquid Limit, Plastic Limit, and Plasticity Index of Soils. American Society for testing and materials, Philadelphia.

Ayala, F.J., Aparicio, V., Sanz Pérez, E. (1987): Análisis del deslizamiento en Inza (Navarra) de 1714-15. Boletín Geológico Minero 98 (3), 404-414.

Benson, C.H., Daniel, D.E. (1990): Influence of Clods on Hydraulic Conductivity of Compacted Clays. Journal of the geotechnical Engineering Division 116 (8), 1231-1248.

Brinkmann, R. (1931): Betikum und Keltiberikum in Sdostpanien. 
Beiträge zur Geologie der westlichen Mediterrangebiete. Abhandlungen der Gesellschaft der Wissenschaften in Göttingen, Mathematisch-Physikalische Klasse, Berlin, 108 p.

Bromhead, E.N., Ibsen, M.L. (2007): An overview of landslide problems in the British Isles, with reference to geology, geography and conservation. In: K. Sassa, H. Fukuoka, F. Wang, G. Wang (eds.), Progress in Landslide Science. Springer, Berlin, pp. 13-25.

BS 1377-7:1990 (1990): Methods of test for soils for civil engineering purposes. Shear strength tests. British Standard, London.

BS 5930:2015 (2015): The code of practice for site investigations. British Standard, London.

Canerot, Y., Cugny, P., Pardo, G., Salas, R., Villena, J. (1982): El Cretácico de la Ibérica central-Maestrazgo. In: El Cretácico de España. Universidad Complutense de Madrid, Madrid, pp. 273-344.

Corominas, J. (1989): Clasificación y reconocimiento de los movimientos de ladera. Monografía 3. Sociedad Española de Geomorfología. Zaragoza, pp. 1-30.

Corominas, J. (2006): El clima y sus consecuencias sobre la actividad de los movimientos de ladera en España. Cuaternario y Geomorfología 20 (3-4), 89-113.

Cruden, D.M., Varnes, D.J. (1996): Landslide Types and Processes. In: A.K. Turner, R. L. Schuster (eds.), Landslide investigation and mitigation. Special Report 247. Special Report 247, Transportation Research Board, National Research Council, Washington DC., pp. 36-75.

Daniel, D.E. (1984): Predicting Hydraulic Conductivity of Clay Liners. Journal of the Geothecnical Engineering Division 110 (2), 285-300.

Dikau, R., Brunsden, D., Schrott, L., M.-L. Ibsen (1996): Landslide Recognition. Identification, Movement and Causes. International Association of Geomorphologists, Publication 5, John Wiley and Sons, Chichester, $251 \mathrm{p}$.

De Santiago, C. (2000): Las arcillas magnésicas de la cuenca del Tajo: caracterización y propiedades. Cuadernos de Investigación 40, C.E.D.E.X. Ministerio de Fomento, Madrid, 230 p.

Fallot, P., Bataller, J.R. (1927): Itinerario geológico a través del Bajo Aragón y del Maestrazgo. Memorias de la Real Academia de Ciencias y Artes de Barcelona, 20 (8), 1-143.

Floquet, M., Alonso, A., y Meléndez, A. (1982): Cameros-Castilla. El Cretácico superior. In: A. García (ed.), El Cretácico de España, Universidad Complutense de Madrid, Madrid, pp. 387-453.

Galán Huertos, E., Martin Vivaldi, J.L. (1974): Caolines españoles: geología, mineralogía y génesis. Boletín de la Sociedad Española de Cerámica y Vidrio, 395-406.

Guzzetti, F., Carrara, A., Cardinali, M., Reichenbach, P. (1999): Landslide hazard evaluation a review of current techniques and their application in a multi-scale study, Central Italy. Geomorphology 31, 181-216.

Hermann, J.G., Elsbury, B.R. (1987): Influential factors in soil liner construction for waste disposal facilities. Geotechnical Practice for Waste Disposal'87. R.D. Woods (ed.), ASCE, New York, pp. 522-536.

Hutchinson, J.N., Bromhead, E.N., Chandler, M.P. (1991): Investigations of the landslides at St Catherine's Point, Isle of Wight. In: R. J. Chandler (ed.), Slope stability engineering - developments and applications. Thomas Telford, London, pp. 169-179.

Itasca Consulting Group, Inc FLAC (2005): Fast lagrangian analy- sis of Continua, Version 5.0 Fluid-Mechanical Interaction. Minneapolis.

Itasca Consulting Group, Inc FLAC3D (2012): Fast lagrangian analysis of Continua, Version 5.0 Explicit Continuum Modeling of Non-linear Material behaviour in 3D. Minneapolis.

Iverson, R.M. (2000): Landslide triggering by rain infiltration. Water Resources Research 36 (7), 1897-1910.

Jiménez-Salas, J.A. (1984): La rotura progresiva en la estabilidad de taludes. Simposio sobre Inestabilidad de laderas en el Pirineo, Barcelona, pp. 41-44.

Lambe, T.W. (1958): The structure of compacted clay. Journal of the Soil Mechanics and Foundations Division, 84 (2), 1-34.

Menéndez-Pidal, I. (2006): Interacción de las arenas en Utrillas facies en las obras de Ingeniería Civil. Revisión documental y caracterización geológica geotécnica. Tesis Doctoral (PhD Thesis). Universidad Politécnica de Madrid. Unpublished.

Msilimba, G., Holmes, P. (2010): Landslides in the Rumphi district of northern Malawi: characteristics and mechanisms of generation. Natural Hazards 54 (3), 657-677.

Richter, C., Teichmuller, R. (1933): Die Entwicklung der Keltiberischen Ketten. Beiträge zur Geologie der westlichen Mediterrangebiete. Abhandlungen der Gesellschaft der Wissenschaften in Göttingen, Mathematisch-Physikalische Klasse, Berlin, 118 p.

Ruiz, M.B., Gil, M.J., Dorado, M., Valdeolmillos, A., Vegas, J., Pérez, A. (2002): Clima y vegetación durante el Tardiglaciar y el Holoceno en la Sierra de Neila (Sistema Ibérico Noroccidental). Cuaternario y Geomorfología 16 (1-4), 9-20.

Sanz, E. (1999): Las Aguas subterráneas en Soria. Colección Temas Sorianos. Diputación Provincial de Soria, Soria, 367 p.

Sassa, K., Wang, G., Fukuoka, H., Wang, F.W., Ochiai, T., Sugiyama, S.T. (2004): Landslide risk evaluation and hazard mapping for rapid and long-travel landslides in urban development areas. Landslides 1 (3), 221-235.

Sharpe, C.F.S. (1938): Landslides and Related Phenomena; a study of mass-movements of Soil and Rock: New York, Columbia University Press, $137 \mathrm{p}$.

Tricalinos, J. (1928): Untersuchungen über den Bau der Keltiberischen Ketten des nordöstlichen Spanien. Zeitschrif Der Deutschen Geologischen Gessellschaft 80, 409-483.

Turner, A.K., Schuster, R.L. (1996): Landslides Investigation and Mitigation. In: A.K. Turner, R.L. Schuster (eds.), Special Report 247, Transportation Research Board. National Research Council, Washington DC, $673 \mathrm{p}$.

USGS (2004): Landslide Types and Processes. U.S. Department of the Interior, U.S. Geological Survey, 4 pp. http://pubs.usgs.gov./ fs/2004/3072/

Varnes, D.J. (1978): Slope Movements, Types and Processes. In: Schuster, R.L. Krizck, R.J. (Eds.), Special Report 176: Landslides: Analysis and Central. Transportation Research Board. National Academy of Sciences, Washington DC, pp. 11-33.

Vilas, L., Mas, J.R., García, A., Arias, C., Alonso, A., Meléndez, N., Rincón, R. (1982): Ibérica suroccidental. In: A. García (ed.), El Cretácico de España. Univ. Complutense Madrid, Madrid, pp. 457-514.

Wang, F.W., Sassa, K., Wang, G. (2002): Mechanism of a longrunout landslide triggered by the August 1998 heavy rainfall in Fukushima prefecture, Japan. Engineering Geology 63 (1-2), 169185. 